\title{
Corporate Tax Planning Activities: Overview of Concepts, Theories, Restrictions, Motivations and Approaches
}

\author{
Mahfoudh Hussein Mgammala \\ Ku Nor Izah Ku Ismail b \\ aSchool of Accountancy (SOA) - COB, Universiti Utara Malaysia, from Amran University, Amran/Yemen \\ Email: alkasermr@gmail.com \\ ${ }^{b}$ School of Accountancy (SOA) - COB, Universiti Utara Malaysia, Sintok, Kedah/Malaysia
}

Doi:10.5901/mjss.2015.v6n6s4p350

\section{Abstract}

Globally, the transformations in the tax systems and accounting standards have been given the firms opportunities to manage their tax affairs for the advantage of their shareholders. Tax planning by companies is a highly important activity as one of many tools uses to manage companies' tax affairs. The main purpose of this paper is to reviews the literature on various aspects of tax planning. This study goes on to review the literature on the concept of tax planning activities for companies. $A$ review of literature on tax planning chances due to 'gaps' in the properties of the law and business taxes, and to discuss how tax planning is carried out with differing measurements and approaches from company to another. In the current setting, in which the tax burden is getting to be progressively important in companies' composition of costs, tax planning is a significant tool to increment competitiveness. However, a few is known about the full extent of consequences and results of tax planning. In this article, we contribute in this area by reviewing related literature to provide better understanding about tax planning.

Keywords: Tax Planning (TP), Effective Tax Rate, Tax Return, Tax Avoidance, Tax Evasion.

\section{Introduction and Background}

Tax is a significant cost for corporations. Therefore, minimizing tax will enhance profitability. Tax liability is a manageable cost that can be decreased, like any operational costs (Garbarino, 2011). It is, consequently, a widely accepted practice in a company's tax administration that, according to their duties of faithfulness and concern towards stakeholders, managers use a duty of care and a duty of loyalty to reduce the company's tax burden. It is undertaken with high levels of diligence, concern, and experience in the belief that this minimization is in the best interest of the corporation (Keinan, 2003). Tax planning is a procedure that organizations, individuals, and businesses utilize to evaluate their financial profile with the purpose of reducing the amount of taxes paid on business profit or personal income.

Research on the activities of tax evasion explains that the term 'tax avoidance' includes any tax planning used legally by businesses to reduce their income tax. The term 'tax evasion' refers to any means of tax planning used, by taxpayers, to decrease the level of tax payments from their source of income. In other words, the term "avoidance" indicates the activities of tax planning and the consequences of ambiguity (intended or unintended) concerning tax laws, policies, or technical aspects (Rego, 2003). Prior tax researchers looked at tax evasion and tax planning as a significant component in the process of tax planning in order to understand the concept of tax planning activities (Rego, 2003). In another definition, Harvey (2011) stated that tax planning can be defined as drawing strategies throughout the year in order to reduce tax liability, for example, by choosing a tax filing status that is most helpful to the taxpayer. Such tax planning can be achieved by waiting until the next tax year to sell an asset, so as not to realize capital gains. Furthermore, tax planning can mean making a company's investment decisions based on determined revenue and current and projected tax laws.

Investigations into the degree to which tax planning responds to differences in state tax policy have influenced the state company's income tax bases and revenues. An aggregation of tax avoidance, evasion, and practices differs from the traditional analysis, but is consistent with recent research, for instance, overstating tax deduction or underreporting taxable income. Tax planning strategies are mostly lawful, but some might fall into a gray area in legal terms, or even employ illegal tactics of blatant tax evasion as an understatement of taxable income or deductions overstated (Bruce, Deskins, \& Fox, 2007).

The rest of this paper offer a review of literature in regards to tax planning, which contains definitions of tax 
planning and discusses the underlying theories of TP research in the literature, concerning the theory and framework of tax planning. Additional sections review the practice of efficient tax planning, counting goals, boundaries, advantages, and motivations of tax planning. The next part of this paper examines literature in the curricula of applicable tax planning, because varying methods for tax planning exist from company to company. Finally, the last part concludes of this paper.

\section{Tax Planning Definitions}

There are many definition of tax planning. It is defined as "the taxpayer's capacity to arrange his financial activities in such a manner as to suffer a minimum expenditure for taxes" (Hoffman, 1961, p. 274). Jeff Pniowsky (2010) defined tax planning generally as being "the process of structuring one's affairs in order to defer, reduce or even eliminate the amount of taxes payable to the government" (Pniowsky, 2010, p. 1). The author found that in Canada tax planning is permitted, provided that it takes place within the provisions set out by the Income Tax Act (ITA). Moreover, tax planning has been identified as the best option, within legal guidelines, to reduce the tax burden. This is achieved through the differing of tax rates between distinctive jurisdictions and economic activities, as well as many of the tax incentives provided under tax laws (Fallan, Hammervold, \& Gronhaug, 1995).

In addition to previously-mentioned literature, Hoffman (1961) argued that, to understand tax planning concepts, tax evasion and tax avoidance should be distinguished. The failure to make any distinction between these separate concepts can guide to the discrediting the allowable tax planning and lead to serious legal consequences (for instance, penalties because of the ignorance of a taxpayer on any lawful side of tax planning). Consequently, it can be concluded that the fundamental terms to clarify the variation between tax avoidance and tax evasion are "legal" and "illegal" (Abdul Wahab, 2010).

Companies expect to take full benefits of allowances and provisions in the tax code so that they pay no more tax than is necessary. Some companies may be more aggressive in their tax planning and look to exploit loopholes or make favorable interpretations of the uncertainty in tax law. Whilst this genre of tax avoidance is legal, many analysts argue that tax avoidance is not in the spirit of the legislation. These tax planning activities are distinct from those covered in the theory of tax evasion, in which firms illegally manipulate their tax liability (Bond, Gammie, \& Whiting, 2012). This is why the majority of companies extensively engage in tax planning with the aim of decreasing their income taxes, as income tax expenses will decrease their profits. In actuality, corporations usually elect to hire a tax agent with the sole purpose of minimizing the taxes they are required to pay (Kristina Murphy, 2004). According to Murphy, tax planning is permitted by the tax regulations as it is considered a lawful tax avoidance system.

Some corporations have the opportunity to carry out tax planning, but because of the advantages and disadvantages connected with tax planning activities, some firms are reluctant to undertake tax planning, whilst other companies are involved in such activities. Noor et al. (2010) claimed that this is because of specific company factors such as the size of the company and its capacities with regards to undertaking tax planning. But the associations between the effective tax rate (ETR) and profitability and size are inconsistent in previous study (Derashid \& Zhang, 2003) because of two diverse theories on the issue of firm size. These two theories are political power theory and political cost theory. The highly profitable firms were found to bear minimum income tax burdens as they used tax incentives and other provisions to decrease their taxable income (Rohaya, Nor Azam, \& Barjoyai, 2008). This, in turn, led to a lower ETR. Besides this, the nature of the business also affected the likelihood of a corporation engaging in tax planning. For example, companies in trading, industrial, technological, plantation, consumer products, services and properties sectors were generally involved in further aggressive tax planning than other sectors, such as companies in infrastructure and construction sectors because of the nature of the business and the limited tax incentives available to them (Noor et al., 2010).

Taking into consideration that different sectors approach tax planning differently, these variations can lead to differing levels of tax burdens (Derashid \& Zhang, 2003). For example in the U.S., the U.S. companies in the textiles, farming, coal products, petroleum and real estate sectors paid significantly minimum income taxes compared to companies in pharmaceutical sectors (Omer \& Molloy, 1991). The reason for this is associated with capital gains and the percentage of depletion allowances given to companies involved in developing, extracting, or mining natural resources. In Malaysia firms involved in the services and trading, construction sectors and properties sectors face high ETRs because they are involved in high level of aggressive tax planning due to various tax incentives eligible for them to utilize. Therefore, the chances for these firms to engage in further aggressive tax planning is increased (Noor et al., 2010). Companies in the infrastructure and construction sectors, however, reported a much higher current-based ETR than others, suggesting that the firms in other sectors engaged in less aggressive tax planning (Noor et al., 2010).

The difference between avoidance and evasion is discussed in detail by Slemrod (2004), who acknowledged that there is no clear line between the two. This leads to varying interpretations of tax planning, often with differing opinions on 
what is "acceptable" and "unacceptable". Hoffman (1961) argued that it could be disputed whether tax avoidance is always 'totally acceptable', as the methods of avoidance employed differ between companies. This situation, in recent years, has been discussed among practitioners, tax authorities, and taxpayers since what is not acceptable to one party may be acceptable to others (Self, 2007). For example, a reduction of stamp duty rates implies an increased incentive for taxpayers to avoid the charges, and the difference in rates for a range of transactions encourage taxpayers to favor one form of transaction instead of another in order to minimize tax costs. Such behaviors will influence what the authorities and governing bodies view as unacceptable tax avoidance (Bowler, 2009).

For clarity, to avoid problems in distinguishing and separating tax avoidance and tax evasion, there are additional studies that determine what is 'acceptable avoidance' and 'unacceptable avoidance'. In view of this, this current study considers tax planning activities including all manners as avoidance and evasion. Following Abdul Wahab (2010), this research defines tax planning activities as a combination of avoidance and evasion. Accordingly, this study focuses on the association between tax planning and tax disclosure, whilst the legal aspects of evasion and avoidance are not empirically examined. When there is prior intent to reduce the tax burden, the procedures are described as passive tax planning activities. In the absence of an earlier intent or purpose, tax planning activities are described as 'effective', although it can be concluded that the activities of tax planning are either active or passive.

According to what has been put forward and discussed previously, any tax planning that can be interpreted as an activity may be defined as either avoidance or evasion. However, although tax authorities mostly view tax avoidance as a legal activity, they also use the term 'acceptable' or 'unacceptable' avoidance to distinguish between differing actions related to tax planning (Slemrod, 2004). Moreover, tax planning can also to be classified as either "active" or "passive", based on the taxpayer's intentions when conducting a transaction. Briefly, tax planning is considered an ongoing issue and is of interest to taxpayers, practitioners, authorities, and researchers. The issues of corporate tax avoidance and evasion are of concern to authorities and researchers as they are associated with public policy. Both activities might deform tax burden distributions and, from an economic viewpoint, could distort resource provisions (Slemrod, 2004).

Finally, tax planning is the act of arranging one's financial affairs to benefit from tax advantages and reduce tax liability as much as possible without breaching tax regulations. Additionally, tax planning is commonly a group of actions. Although the selection of a course of action may take one of various forms, the decision should be made on the basis of predicted tax consequences. Tax planning requires a practical and thorough knowledge of the regulation, of what to do and what not to do, how far to go, and when to stop.

\section{Theories of Tax Planning}

Tax planning activity theories introduce concepts and principles that are typically applicable to tax practitioners. Tax planning could not be continued for long except if the activities of tax planning are "flexible", meaning of a continuity of the strategies (Hoffman, 1961). This is particularly applicable to the cases of tax planning strategies that depend on tax regulation ambiguities and loopholes. Thus, tax planning strategies must be time-oriented and proportionate in the logic that "consistency requires that the past limit the present and the future but the present must be further circumscribed in the light of the taxpayer's future requirements" (Hoffman, 1961, p. 280). Furthermore, tax planning must be "personalized and coordinated', meaning made to form, i.e., fit the subject taxpayer. It also should be with different approaches and types of taxes with "a resolving of conflicting interests", as well as being "completely honest", acting in good faith and maintaining moral responsibility for any behavior's undertaken in the process (Hoffman, 1961).

According to the above-mentioned principles, Shackelford and Shevlin (2001), when studying the income tax research development in accounting, highlighted that the Scholes-Wolfson framework adopts a positive approach in interpreting the function of taxes in organizations. Scholes et al. (2008) explained that the Scholes-Wolfson tax planning framework proposes three significant principles in tax planning: 1) a multilateral approach, for example, all contracting parties could refer to both employers and employees' taxes; 2) the importance of unseen taxes (as an illustration, 'all taxes' could refer to extensive tax forms, such as explicit taxes-the tax paid to the authority-and implicit taxes, which are tax-induced decreases in pre-tax rates of return); 3) the importance of non-tax costs. "All costs" could mention management incentives and trade-offs, and transaction costs between company financial accounting targets and tax targets. The themes are detailed as follows: "all contracting parties must be taken into account in tax planning; importance of hidden taxes-all taxes must be taken into account; and importance of non-tax costs-all costs of business must be considered, not just tax costs"(Scholes et al., 2008, p. 3). 


\section{Tax Planning Objectives}

As argued by the American Institute of CPAs (AICPA), tax planning has two main objectives. The first is to minimize the overall income tax liability, whilst the other is to fulfil financial planning aims with minimal tax results (AICPA, 2015). These goals are achieved through three broad strategies. The first aims to reduce the income tax resulting from an arrangement or a transaction. The second involves shifting the timing of a taxable event, and the third relates to shifting income to another taxpayer, thus, reducing tax liability (AICPA, 2015). According to AICPA it is clear that the main objective of TP is to reduce the tax burden. This, therefore reduces the cost of tax liabilities. This means that tax-payers can take advantage of their ability to reduce tax liabilities in order to achieve the goal of TP as explained clearly by Hoffman (1961). Alternatively, tax planning is viewed from two different perspectives. The first, due to the negative impact of managerial opportunism, is the view that TP is on par with tax evasion. The other orientation offers a direct solution to this problem. If conducted properly, TP activities undertaken within the tax law benefit both managers (agent) and shareholders (principal) and can reduce the tax burden borne by each party through effective TP strategies (Minnick \& Noga, 2010; Sabli \& Noor, 2012).

Efficient TP works to reduce the tax burden whilst, at the same time, does not bear any costs. This means that TP must be practiced with skill and adequate knowledge. It is also significant to observe that the best and optimal target for TP is to maximize the returns after taxes, because the goal of reducing taxes will contribute to the creation of non-tax costs (Scholes et al., 2008). On the contrary, it is also important to note that not all the activities of TP necessarily decrease the tax liability to one's required lowest level, because there is no certainty in TP due to the possibility of nontax costs (Hoffman, 1961). The prime objective of TP is to present all items of a financial plan in the most tax-efficient way possible (Atlas, 2011). Based on the above, the objective of TP should take into account all the components of the financial plan in order to avoid contributing to the creation of new costs borne by the company and help reduce the tax burden in line with the requirements of effective planning for the work of the organization as a whole (Scholes et al., 2008). On the other hand, the objective of TP is not to evade payment of tax, but for a taxpayer to optimize his or her tax exposure (Badertscher, Katz, \& Rego, 2011). In many cases, the primary goal of TP is the application of the laws in such a way they allow business or an individual to reduce the amount of taxable income in any given period. Thus, planning for taxes requires the knowledge of which types of income are currently entitled to be free of taxes. The process also necessitates an understanding of what types of expenses can be considered as legitimate deductions and any conditions that can be used in the application for tax deductions (Jones \& Rhoades-Catanach, 2005).

\section{Tax Planning Restrictions}

In order to achieve the objectives of tax planning listed above, firms face some difficulties and obstacles. For that reason, they must adopt optimal tax planning, taking into account the effects of tax planning on "all costs", "all parties", and "all taxes" (Scholes et al., 2008). Previous studies confirm the importance of the costs of tax planning in several cases; this has made it possible to interpret the restrictions and their effects through costs and non-tax costs. Moreover, these costs must be examined before embarking on the activities of tax planning because the process of tax planning and reduction of taxes can be costly. Thus, the activity will continue only if the costs are predicted to be less than the expected tax cuts. These conditions would not be favorable if the government later increases the company's tax rates in response to minimum tax revenues (Tran-Nam \& Evans, 2000; Rego, 2003; Slemrod, 2004; Rego \& Wilson, 2012).

Generally, the costs incurred by companies due to tax planning emerge from the current tax planning strategies in place. As discussed earlier, there are two types of costs incurred in tax planning. The first is the costs that arise as a result of practicing tax planning now, whilst the other is related to future costs, appearing in accordance with the additional activities of tax planning through the pursuit of the application of new methods of tax planning in the future (Curry, Hill, \& Parisi, 2007).

\subsection{Direct Costs}

Corporations bear legal costs as part of the cost of compliance to ensure the goal of tax planning. This is because of the limitations of judicial branches and legislative in the planning of taxes. The IRS and the courts may challenge the tax planning strategies utilizing judicial doctrines and legislative. Legal costs of tax planning can also be associated with foreign aid, for instance, costs related with tax-associated fees paid to lawyers, accountants and further relevant parties (Howell O'Neill, 2012). Additionally, in a study to investigate investments in tax planning (including in home countries), further costs of foreign aid and expenses in the conduct of tax planning were found (Hanlon \& Heitzman, 2010). O'Neill 
(2012) defined the 'home' costs as the cost of salaries for the company and the IRS, including fringe benefits. Direct costs are cash flows that must be incurred straight by the tax planners in order to achieve the goal of tax planning. These costs include the costs of taxes and lawful advice (Jones \& Rhoades-Catanach, 2005; Schreiber \& Fuehrich, 2007; Armstrong, Blouin, \& Larcker, 2012).

\subsection{Indirect Costs}

A system (production efficiency) of neutral tax makes tax planning ineffective and avoids both direct costs of tax planning (tax costs and legal advice, as well as the cost to the government to tackle tax evasion). Indirect costs arise because the taxpayer changes his financing plans in the existence of taxes and his investments (deadweight loss) (Schreiber \& Fuehrich, 2007; Howell O'Neill, 2012). Furthermore, director compensation and reputation, political costs, and implicit tax are additional indirect costs that are significant considerations in tax planning. Executive compensation could suffer in the case of performance-based remuneration, which decreases remuneration and the reporting income. This could be looked upon as tax disadvantageous for the corporation's administration that rely on performance-based rewards for employees, particularly in granting financial motives for managers (Stapledon, 2004).

Previous literature provides some evidence that managerial incentives impact tax planning options. Nevertheless, there is only a few evidence associated with the precise incentives of the tax directors, who directly participates in the tax decisions of a firm (Armstrong et al., 2012). Conflicts exist because of the reputation that reflects the compensation of managers, and the political costs and implicit costs. Nevertheless, it is significant to observe that the impact of financial reporting and tax planning can operate in two ways, affecting the choices of financial accounting and tax planning (Shackelford \& Shevlin, 2001). However, one important restriction to this model is that shareholders cannot monitor the compensation contract or know whether managers are engaging in lawful tax planning or unlawful tax evasion (Armstrong et al., 2012).

In line with the result that equity risk-taking incentives encourage managers to undertake further aggressive tax planning, Rego and Wilson (2012) found a positive relationship between stock return volatility and a company's tax aggressiveness. However, tax planning also imposes important costs on companies and their managers. They asked managers to invest essential resources in the form of fees paid to attorneys and accountants, in addition to the time that they and their employees devote to planning and resolving tax authority audits. Costs can raise significantly if tax authorities are successful in challenging an aggressive tax position (Rego \& Wilson, 2012).

\section{Tax Planning Motivations and Advantages}

The expected advantages for taxpayers are the primary motivation behind tax planning. Nevertheless, decision makers may employ widely differing levels of aggressive tax planning, which may rely on their individual attitudes (Abdul Wahab, 2010). For example, in the case of risk aversion, decision makers would probably take decisions that involve less risk and, even, low yields, whilst, on the other hand, risk-takers prefer to aim for high yields, despite the high risks associated with this decision. The advantages of tax planning positions are explicit. They decrease tax liabilities, which increase cash flow and can also raise after-tax net income (King \& Sheffrin, 2002).

Discussions on the factors that could stimulate the decision to implement tax planning provide an incomplete explanation of the moderating effects of tax planning. In the process of decision-making tax planning, factors of moderation are the factors that indirectly drive or prevent taxpayers in undertaking tax planning activities (Abdul Wahab, 2010). Utility theory explains that taxpayers' decisions are made on the basis of an expectation that they will receive the highest benefits possible when considering the trade-off between the risks from decisions made and the expected returns (tax saving). Alternatively, prospect theory explores taxpayers' decisions beneath safe and guaranteed conditions in which the taxpayers favor a tax planning strategy that is seen as low risk, even though the tax saving is lower. These attitudes could be more interpreted in relation to prospect theory and expected utility theory (King \& Sheffrin, 2002). However, risk-takers, in line with probable usefulness theory, embark on tax planning strategies that offer the highest tax savings, whereas risk-averse taxpayers, according to prospect theory, favor a strategy that includes low risk and merely contracts with standard reductions (King \& Sheffrin, 2002).

Based on the motivating factors that encourage companies to take tax planning, corporations engage themselves in tax planning for the primary benefits that result from a rise in after-tax returns. Likewise, as pointed out by various theories and definitions of tax planning, it is significant to note that after tax returns could be unenthusiastically influenced by tax minimization, although tax minimization might be seen as an advantage of tax planning. This is because of the likelihood of a tax minimization strategy to draft in important expenses of a non-tax dimension, as discussed in the part of 
restrictions of tax planning previously. Additionally, Shackelford and Shevlin (2001) claimed that tax minimization advantage could result in other non-tax costs, for instance, lower reported revenue. Besides that, the Scholes-Wolfson framework argues that, because of its possible negative impact on after-tax returns, tax minimization is not the best benefit in tax planning. For instance, in order to maximize tax, one could merely not invest in profitable ventures. Consequently, the addition of after-tax returns is the major objective of efficient tax planning instead of tax minimization (Scholes et al., 2008).

Furthermore, compared to after-tax income, raised cash inflows would be an advantage to the taxpayers by a rise of cash obtainable through corporations, with consideration to only the tax paid rather than tax cost. Besides a rise in after-tax returns, tax planning is also an advantage to the corporations in the form of cash inflows (Jones \& RhoadesCatanach, 2005). Based on the foregoing discussion, the cash inflow advantage of taxation may be connected to the timing or delays of tax planning strategies. Additionally, incremental cash flow advantage is obtainable by way of lesser tax rates flanked by interrelated corporations.

\section{Tax Planning Measurements}

Tax planning measures used in earlier studies vary, depending on the accessibility of data and the interest of researchers in the general or specific approach to tax planning. Prior researchers utilized different measures of tax planning utilizing both privately and publicly accessible data. In measuring the results of tax planning, they can assess a tax measure to be appropriate because it exhibits the gap between the taxes burden-based "book reports" and "taxable income-based". Several studies on tax, either indirectly or directly, deem a tax saving to be the result of such tax planning. The mainly popular measures utilized by researchers are book-tax gaps (Plesko, 2003; Hanlon \& Heitzman, 2010) and effective tax rates (Mills, Erickson, \& Maydew, 1998; Abdul Wahab, 2011; Rego \& Wilson, 2012). The measure of tax saving is a constant issue amongst researchers due to a debate on the accuracy of measures in exhibiting tax planning activity (Armstrong et al., 2012). This is because tax burden-associated data cannot be accessed by external interested parties. In addition, effective tax rate is also a suitable measure of tax planning as compared to book-tax gap measure since it can remove measurement errors associated with tax expense on tax credit and foreign income (Hanlon \& Heitzman, 2010 Abdul Wahab, 2011).

\section{Tax Planning Approaches}

There are many approaches that can be used by firms in the implementation of tax planning activities. Approaches that are discussed in this segment include participation in the profit or income change and changes in income properties and re-organization and participation in tax-free or tax-favored investments (Abdul Wahab, 2010). Tatum (2012) highlighted three common approaches to tax planning which aim to decrease the tax burden. The first is a reduction of the adjusted gross income for a given taxable year (this is where the understanding of recent tax regulations in relation to exemptions and allowances becomes relevant). The second approach to tax planning is to increase the amount of tax cost. This means knowing the recent regulations and their application and when to apply to all normal and customary expenses related to the family or company is important. Because these may change from one year to the next, it is always a good idea to check the local laws. A final approach that is appropriate to effective tax planning concerns the use of tax exemptions. This includes claims relating to college expenses, retirement savings plans, and many other credits. A common instance of the tax credit is the earned income credit, which aims to ease the tax burden for people who earn less than a certain amount in a given calendar year (Tatum, 2012). Nonetheless, Curry et al. (2007) argued that these methods do not specifically and properly describe the approach to tax planning in a future of uncertainty, as they require ease of detection by the authorities. Their research suggests that, in a scenario where certain strategies have been adopted by taxpayers, the authorities may gain information to aid their efforts in decreasing or preventing the option of tax planning by that exacting approach. In following subsections some approaches of tax planning are discussed.

\subsection{Income Shifting}

In applying income shifting approach, taxpayers adjust the nature of their incomes so that income or profit is connected with parties that are subject to inferior tax jurisdictions (Abdul Wahab, 2010). Sharing of profits or income-shifting occurs in the situation of tax provisions through time and diverse tax rates, the site, and types of income (Slemrod, 1995). For instance, transferring profits to branches in dissimilar tax jurisdictions when tax planning is a concern for authorities as it has numerous negative implications, as argued by Gordon and Slemrod (2002). These include misguiding distributional 
statistics, misguiding corporate rates of return, and negative results on the efficiency in estimating the marginal surplus burden produced from any change of tax. Based on the Scholes-Wolfson framework, corporations may turn out to be participating in tax planning during income-shifting or profit-sharing by transferring the revenue from "one pocket to another pocket", or shifting revenue geographically (transferring profits to a business premises with lesser tax jurisdictions and shifting the income over time).

Dharmapala and Riedel (2012) supported the hypothesis of income tax-motivated transformation, using a different identification approach called 'a difference-in-difference approach' than those used in the previous studies. Differenceindifference approach was developed by Dharmapala and Riedel (2012) to estimate the magnitude and existence of taxmotivated income shifting among multinational companies, as the study focused on how a given earnings shock to the parent firm affects low-tax subsidiaries differently than high-tax subsidiaries. Thus, this approach enhances and enriches the sources of evidence on this issue. For example, one cannot rule out the possibility that the results of profit conversion are only an artifact of the effects of time of a specific pairing of countries. In quantitative terms, the estimates indicate that the transfer is a margin of about two percent of the home country's gain (additional) for the low-tax subsidiary. This represents a significant impact, even if it is slightly lower than those found in earlier literature, assuming changes in the rates of company as a source of identity. On the other hand, the fact that these estimates are larger in size indicates that the current legal and economic differences (such as transfer pricing regulations and the rules of thin-capitalism) of the bond tax planning play an important role (Dharmapala \& Riedel, 2012).

\subsection{Modification of Income Characteristics}

In the U.S. state business tax planning study, Bruce et al. (2007) illustrated that firms may reclassify trade income as nonbusiness income and transport it to a low-tax or no-tax state in order to decrease the state tax burden. By reclassifying a non-business income as a business income, a corporation may decrease the tax burden, whilst the business income would be desirable for a capital allowance reduction and business losses reductions. The taxpayers might be participating in tax planning during the modification of the nature of an income. This is mainly connected to the income-shifting strategy, as it supplies a chance for firms to change the nature of the income from domestically-received to foreign income. Additionally, companies may follow tax planning by shifting the nature of an income during adjustment from income-revenue in nature to capital gain in nature. In the case of reduced capital gain tax rates in relation to income tax rates, this strategy is efficient. Similarly, a corporation may also be participating in tax planning by shifting the nature of an income from a business to non-business income or vice versa.

\subsection{Organizational Structure}

Reorganization is a further tax planning approach that may be adopted by some corporations. Desai and Dharmapala (2006) highlighted the fact that any prediction of the directional correlation between tax planning and equity incentives is subject to the corporate structure. However, it is not clear how a group manager is capable to extract rents from the company (Armstrong et al., 2012). In a case-study of conglomerates, Stonham (1997) documented that, in 1996, corporations benefited from their tax planning through a demerger strategy in which they successfully achieved the U.S. tax authorities' agreement of a tax-free sharing of the stock dividend to their nationals. This allowed the corporations to gain some advantages in the form of tax exemption, a tax shield and a lesser tax bill. Nevertheless, a taxpayer must conduct a comprehensive examination before accepting this approach because of various differing structures and the difficulty of a demerger. On the other hand, tax planning can be taken via reorganizations by both international and domestic corporations. Moreover, the reorganizations by domestic firms include share reorganizations, mergers and demergers, amalgamations, reconstructions, management buyouts and share purchases, whilst international corporations may be engaged in transformation from subsidiary to branch or vice-versa, or multinational mergers and reorganizations (Abdul Wahab, 2011).

A\&L Goodbody (2012) found, for instance, that Henderson and Accenture, were observed to migrate their company-holding corporations from the U.S. to Ireland to enjoy tax planning advantages while the latter supplied tax incentives to holding corporations, such as domestic exemptions from withholding tax, exemption on qualified capital gains, and lesser tax rates on Ireland-derived trading income. Likewise, a tax planning approach during reorganization could be approached by changing the residential situation of a firm. This strategy is also mentioned to as "company migration" or "company inversion" (A\&L Goodbody, 2012). Tax planning during the organizational structure could be achieved through disintegration, migration of companies, and a reflection of the companies (Abdul Wahab, 2010). 


\subsection{Tax-Exemption}

In line with the aforementioned tax planning approaches, dealing with tax-favored or tax-exempt investments is an efficient tax planning approach. Tax exemption involves a person or organization not being taxed on a purchase or income that normally would be subject to some form of taxes. Some tax systems provide tax exemptions to organizations of people, items of property, taxable income, and others, under order. Tax credit may also refer to a personal exemption allowance or type of currency (Manzon \& Plesko, 2002). This occurs when the firm claims for exemption to reduce one type of taxable income. Moreover, tax credits can provide the payment of taxpayers' tax in full, whilst other cases may be subject to a reduced rate, or partially subject to tax (Scholes et al., 2008). Tax-favored investments may enjoy numerous types of tax-favored status; for instance, and tax credits and full tax exemption, actually, the investment might enjoy further than one tax-favored status. It is known that tax-favored investments are clearly taxed more lightly than fully taxable bonds (Scholes et al., 2008).

\section{Conclusion}

Tax planning is a wide term that is utilized to depict the procedures used by people and organizations to pay the taxes. In general, depended on the literature discussed in this paper, TP essentially refers to avoidance and evasion. In this context, TP is defined in general as being the procedure of structuring one's affairs in order to postpone, decrease or even eliminate the amount of taxes payable to the government. Numerous TP approaches have been identified, including income shifting, modify of characteristics of income, organizational structure and tax-exemption. The primary motivations for undertaking TP are the expected financial benefits. By reviewing the different literature, it can be concluded that there are many aspects of TP needs to be covers by researchers in the future to fill the gap in the body of knowledge.

\section{Acknowledgements}

We appreciate helpful comments provided by: Nor Shaipah Abdul Wahab, Senior lecturer in Accounting at the Southampton Management School University of Southampton/United Kingdom. We are grateful as this paper has benefitted from her and referees constructive comments. Finally the financial support from the Universiti Utara Malaysia is gratefully acknowledged

\section{References}

A\&L Goodbody. (2012). Corporate migration to Ireland. Legal News. Retrieved 28 March, 2012, from http://www.algoodbody.com/en_nl/ legal-news-2012.aspx

Abdul Wahab, N. S. (2010). Tax planning and corporate governance: Effects on shareholders valuation. Thesis for the degree of Doctor of Philosophy, University of Southampton, Southampton UK. Retrieved 5 November, 2011, from http://eprints.soton.ac.uk/ 162801/.

Abdul Wahab, N. S. (2011). Director' pay: Significance as a tax-motivated expense allocation. Paper presented at the Second International Conference on Business and Economic Research, Malaysia. Retrieved 7 March, 2012, from http://www.international conference.com.my/proceeding/2ndicber2011_proceeding/218-2nd\%20ICBER\%202011\%20PG\%201001-1012\%20Directors\% 20Pay.pdf.

AICPA. (2015). Introduction to personal income tax planning. Retrieved 27 August, 2015, from http://www.aicpa.org/interestareas/ personalfinancialplanning/cpeandevents/pages/tax-events.aspx

Armstrong, C. S., Blouin, J. L., \& Larcker, D. F. (2012). The incentives for tax planning. Journal of Accounting and Economics, 53(1), 391-411.

Atlas, M. I. (2011). Canadian Taxation of Non-Residents (4th ed.). Toronto: CCH Canadian, Limited.

Badertscher, B., Katz, S. P., \& Rego, S. O. (2011). The Impact of Private Equity Ownership on Portfolio Firms' Corporate Tax Planning. Boston: Harvard Business School.

Bond, S., Gammie, M., \& Whiting, J. (2012). Tax avoidance. The IFS Green Budget January 2012. Retrieved 14, February 2013, from http://www.ifs.org.uk/budgets/gb2012/gb2012.pdf

Bowler, T. (2009). Countering Tax Avoidance in the UK: Which Way Forward? London: The Tax Law Review Committee Institute for Fiscal Studies.

Bruce, D., Deskins, J., \& Fox, W. F. (2007). On the extent, growth, and efficiency consequences of state business tax planning. In A. J. Auerbach, J. R. J. Hines \& J. Slemrod (Eds.), Taxing Corporate Income in the 21st Century. Cambridge United Kingdom: Cambridge University Press, 226-256.

Curry, P. A., Hill, C. A., \& Parisi, F. (2007). Creating failures in the market for tax planning. Virginia Tax Review, 26(4), 943-969. 
Derashid, C., \& Zhang, H. (2003). Effective tax rates and the "industrial policy" hypothesis: Evidence from Malaysia. Journal of International Accounting, Auditing and Taxation, 12(1), 45-62.

Desai, M. A., \& Dharmapala, D. (2006). Corporate tax avoidance and high-powered incentives. Journal of Financial Economics, 79(1), 145-179.

Dharmapala, D., \& Riedel, N. (2012). Earnings shocks and tax-motivated income-shifting: Evidence from European multinationals. Journal of Public Economics, 97(11-12), 95-107.

Fallan, L., Hammervold, R., \& Gronhaug, K. (1995). Adoption of tax planning instruments in business organizations: A structural equation modelling approach. Scandinavian Journal of Management, 11(2), 177-190.

Garbarino, C. (2011). Aggressive tax strategies and corporate tax governance: An institutional approach. European Company and Financial Law Review, 8(3), 277-304.

Gordon, R. H., \& Slemrod, J. (2002). Are" real" responses to taxes simply income shifting between corporate and personal tax bases? (No. 0898-2937): National Bureau of Economic Research. Retrieved 13 May, 2012, from http://www.nber.org/papers/w6576.

Hanlon, M., \& Heitzman, S. (2010). A review of tax research. Journal of Accounting and Economics, 50(2), 127-178.

Harvey, C. R. (2011). Tax planning. Retrieved 4 July, 2012, from http://financial-dictionary.thefreedictionary.com/Tax+Plan

Hoffman, W. H. (1961). The theory of tax planning. The Accounting Review, 36(2), 274-281.

Howell O'Neill, J. (2012). Innovation and constraints on tax shelters. Faulkner Law Review, 4(1), 1-35.

Jones, S., \& Rhoades-Catanach, S. (2005). Advanced Strategies in Taxation (4th ed.). New York: McGraw-Hill.

Keinan, Y. (2003). Corporate governance and professional responsibility in tax law. Journal of Taxation and Regulation of Financial Institutions, 17(1), 10-25.

King, S., \& Sheffrin, S. M. (2002). Tax evasion and equity theory: An investigative approach. International Tax and Public Finance, 9(4), 505-521.

Kristina Murphy. (2004). Aggressive tax planning: Differentiating those playing the game from those who don't. Journal of Economic Psychology, 25(3), 307-329.

Manzon, G. B., \& Plesko, G. A. (2002). Relation between financial and tax reporting measures of income. Tax Law Review, 55(1), 175214.

Mills, Erickson, M., \& Maydew, E. (1998). Investments in tax planning. Journal of the American Taxation Association, $20(1), 1-20$.

Minnick, K., \& Noga, T. (2010). Do corporate governance characteristics influence tax management? Journal of Corporate Finance, 16(5), 703-718

Noor, R. M., Fadzillah, N. S. M., \& Mastuki, N. A. (2010). Corporate tax planning: A study on corporate effective tax rates of Malaysian listed companies. International Journal of Trade, Economics and Finance, 1(2), 1238-1242.

Omer, T. C., \& Molloy, K. H. (1991). Measurement of effective corporate tax rates using ?nancial statements information. The Journal of the American Taxation Association, 13(1), 57-72.

Plesko, G. A. (2003). An evaluation of alternative measures of corporate tax rates. Journal of Accounting and Economics, 35(2), 201226.

Pniowsky, J. (2010). Aggressive tax planning-How aggressive is too aggressive? Thompson Dorfman Sweatman LLP, 3, 1-3. Retrieved 18 June, 2012, from http://www.tdslaw.com/newsletter/2010/Oct/articles/aggressive_tax_planning.pdf.

Rego. (2003). Tax-avoidance activities of U.S. multinational corporations. Contemporary Accounting Research, 20(4), 805-833.

Rego, \& Wilson, R. (2012). Executive compensation, equity risk incentives and corporate tax aggressiveness. Journal of Accounting Research, 50(3), 775-810.

Rohaya, M. N., Nor Azam, M., \& Barjoyai, B. (2008). Corporate effective tax rates: A study on Malaysian public listed companies. Malaysian Accounting Review, 7(1), 1-20.

Sabli, N., \& Noor, R. M. (2012). Tax planning and corporate governance. Paper presented at the International Conference on Business and Economic, 12-13 March Golden Flower Hotel, Bandung, Indonesia. Retrieved 30 July, 2012, from www.Internationalconference.Com.My.

Scholes, M. S., Wolfson, M. A., Erickson, M., Maydew, E. L., \& Shevlin, T. (2008). Taxes and Business Strategy: A Planning Approach (4th ed.). New Jersey: Pearson Prentice Hall.

Schreiber, U., \& Fuehrich, G. (2007). European group taxation-formula apportionment versus current inclusion. Retrieved 22 April, 2012 , from http://www.ssrn.com/abstract=964009

Self, H. (2007). Acceptable tax avoidance? In A. Lovejoy (Ed.), In My Opinion: Acceptable Tax Avoidance? London: The Tax Journal, 910.

Shackelford, D. A., \& Shevlin, T. (2001). Empirical tax research in accounting. Journal of Accounting and Economics, 31(1-3), $321-387$.

Slemrod, J. (1995). Income creation or income shifting? Behavioral responses to the tax reform Act of 1986. The American Economic Review, 85(2), 175-180.

Slemrod, J. (2004). The economics of corporate tax selfishness. National Tax Journal, 57(4), 877-899.

Stapledon, G. P. (2004). Pay for performance dilemma. Griffith Law Review, 13(1), 1-57.

Stonham, P. (1997). Demergers and the Hanson experience. Part two: Demerger tactics. European Management Journal, 15(4), 413422.

Tatum, M. (2012). What is tax planning? Retrieved 5 May, 2012, from http://www.wisegeek.com/what-is-tax-planning.htm

Tran-Nam, B., \& Evans, M. (2000). Tax compliance costs: Research methodology and empirical evidence from Australia. National Tax Journal, 53(2), 229-252. 